\title{
6.4 Tertullian and Religious Identity
}

The landscape of ancient North African religion includes a wide array of interactions between various cults and religious practices. In one sense scholars could not elaborate on Tertullian's writings outside of the category of religion in that every treatise of his is written from a Christian perspective and within religious dialogue. Such an oversimplification of Tertullian's works, however, should not negate the interwoven aspects of social identities, kinship, class, ethnicity and other elements which also permeate his writings. The web of complexity in his construction of a social universe actually provides the scholar with the ability to view any one work or subject in Tertullian's writings from many different approaches asking a variety of questions. One such question is regarding Tertullian's religious opponents and dialogical counterparts. Because so much of his work is apologetic or polemic, a focus on those whom Tertullian challenged, both Christians and non-Christians, offers insights into his arguments and identity.

\subsubsection{African Christian and Roman Non-Christian Religious Identities}

Roman persecution of Christians significantly affected the self-understanding of many North African Christian communities. During one of the outbreaks of persecution against Tertullian's congregation, he produced Ad martyras, a tract written to encourage and edify those awaiting torture and death in prison. Although the letter published under its current form at a later date, it betrays no signs of having been written to a wider audience than the martyrs themselves and does not explicitly reference any concern for a wider audience. ${ }^{87}$ Whether Tertullian speaks in a pseudo-correspondence for rhetorical effect or whether the treatise represents an actual epistle to specific individuals can likely never be demonstrated conclusively. ${ }^{88}$ Tertullian's work does indicate, however, a clear conflict between his religious community and that of non-Christians, a fact unreservedly accepted among scholars. The following analysis of Ad martyras seeks to further this understanding by exploring the textual construction of that religious conflict as directed against not only non-Christians generally, but more specifically, as conflict with non-Christian Romans.

In establishing the Christians' opponent in Ad martyras, Tertullian specifies that the true persecutors of those awaiting torture are not merely the human agents, but the cosmic forces opposed to the Christian God at work in those humans. Tertullian celebrates with the martyrs that their imprisonment has separated them "from the world" (a mundo, 2.1 ) so they no longer have to look on

87 cf. Ad ux. Similarly, Tertullian can speak directly to heretics thetorically, but still address a wider readership (e.g. Adu. Marc., Adu. Prax., Adu. Val., etc.)

88 Schlegel, "The Ad martyras," 125-128, argues for the latter. 
"strange gods" (alienos deos, 2.7). Such an understanding of martyrdom should come as no surprise to Tertullian's audience, as indicated in his reminder, "We were called to the warfare of the living God in our very response to the sacramental words" (uocati ad militiam sumus Dei uiui iam tunc, cum in sacramenti uerba respondemus, 3.1). In other words the Christians' baptismal confession included a rejection of idolatry and a pledge to do battle with the devil. $^{89}$ More can be said, however, about Tertullian's precision in describing religious oppressors in terms beyond an exclusively Christian/non-Christian dichotomy.

Nowhere in Ad martyras does Tertullian make reference to any provincial gods or cults, African or otherwise; instead, he repeatedly alludes to Rome as "the world" (saeculum) and the challenges it represents to the Christians. ${ }^{90}$ Moreover, Tertullian develops his discourse with a Rome/Carthage dichotomy in terms largely encoded for insiders. He describes the Roman prison in which the martyrs are held as "the devil's house" (Domus... diaboli est, 1.4) and challenges the Christians to defeat the devil in "his own kingdom" (in suo regno, 1.5) by being "armed and fortified with concord" (munitos et concordia armatos, 1.5). The use of "Concord," part of the complete title given to the reconstructed city of Carthage - COLONIA IULIA CONCORDIA KARTHAGO - would have been recognized by any inhabitant of the city. ${ }^{91}$ Tertullian then declares that this "world," not the martyrs, is actually awaiting judgement, and that "not of the proconsul, but of God" (non proconsulis, sed Dei, 2.3).

At the end of his treatise, he supplies another subtle attack on Rome by comparing the worthy purpose of Christian martyrdom with the many who supported the emperor, alluding sardonically to the many who died for a "mere human being's cause" (hominis causa, 6.2). ${ }^{92}$ While the identification of Rome as the enemy would be natural for Christians under persecution (e.g. the New Testament book of Revelation), Tertullian formulates his religious "Other" precisely in Roman/African terms. ${ }^{93}$ The language is not limited to merely Christian and non-Christian terminology, but instead includes political/regional

89 Harrill, "The Influence," 275-82, sees in Tertullian's words (and Cyprian, Epistulae 69.7.1-2; $70.2 .1 ; 73.4 .2$ ) influence of Roman contract law, that was a practice common to the everyday experience of those in the Roman empire at this time.

90 saeculum is used nine instances (counting saecula saeculorum, 3.3 as twice, in which case it is the Christian age to come), seven of which are in chapter two.

91 Rives, Religion, 44. Tertullian elsewhere references Concordia as symbolic of Carthage (De pall. 1.2; in fact, it is specifically in contrast to the toga as a symbol of Rome); see comments in Barnes, Tertullian, 85.

92 For a discussion of this reference to Septimius Severus' rise to power and suppression of rivals, see Barnes, Tertullian, 32-3; this reference to Severus' defeat of Albinus in 197 leads Barnes to date Ad martyras in the latter part of that year. For the ancient witnesses, see Dio Cassius 75.8 , 76.4; and Herodian 3.8.12. On the ironic, hominis causa, cf. Scriptores historiae augustae, Seuerus, 11, where Septimius deified Commodus in response to the Senate's alleged support of Albinus.

93 Tertullian explicitly does so, citing the biblical book of Revelation in De res. car. 24-5. 
references that one would expect to find in a postcolonial treatise. ${ }^{94}$ One passage in the Ad martyras expressly evidences the subversive tone Tertullian applies to the social context of the martyrs.

As part of his exhortation to faithfulness, Tertullian provides those awaiting martyrdom with a long series of examples (4.4-7). Gerald Bray in his book, Holiness and the Will of God: Perspectives on the Theology of Tertullian, notes the peculiarity of this list, observing, "The 'martyrs' whom he celebrates are not even Christians - a highly revealing fact. All of them without exception are figures drawn from pagan history and mythology. Obviously, fidelity to Christ was not the most important element in Tertullian's definition of a martyr!" 95 What, then, was the "most important element" in Tertullian's definition of a martyr? One might suspect that Tertullian is limited by a lack of Christian examples of martyrdom available at the time, and he must, therefore, draw from non-Christian heroes to present acts of bravery in the face of torture and death. ${ }^{96}$ Does Tertullian not know of the Scillitan martyrs who died in North Africa around 180, or about Perpetua, Felicitas and their fellow-martyrs who died in $203 ?^{97}$ If he is writing before these events, surely he does know about the beheading of Paul, the martyrdom of Peter, the stoning of Stephen or the crucifixion of Jesus. None of these men, however, are offered as examples to the martyrs. Perhaps, given the socio-political landscape of his time, elaboration can be made on the "martyrs" Tertullian does cite.

The complete list of exempla include Lucretia's suicide after being raped, Mucius' burning of his hand before his captors, Heraclitus' suffocating himself in overheated dung, Empedocles' casting himself into the volcano, Peregrinus' immolating himself at the Olympic games, Dido's suicide in her pyre, Hasdrubal's wife's suicide in the burning of Carthage, Regulus' refusal to negotiate resulting in his death by multiple stab wounds, Cleopatra's suicide by viper and Leena's biting off of her own tongue. ${ }^{98}$ Could these "martyrs" signify anything to Tertullian's audience other than commendable suffering?

Although Dido is portrayed by Virgil as a "furious" or, one could arguably translate, "hysterical" (e.g. 'furens,'Aen. 4.69 and furibunda, 4.446) woman who immolated herself after being abandoned by Aeneas, the pious founder of Rome, she often appears in Tertullian's works, along with Hasdrubaal's nameless - in

94 Altaner, Patrology, 167, says Tertullian "attacked and ridiculed the pagan religion in general." When one examines $A d$ martyras (and his writings on a whole), however, many passages indicate specific opponents, not merely "pagan religion in general" as found in previous apologists.

95 Bray, Holiness, 45.

96 Sider, Ancient Rhetoric, 117-8; and Tilley, "The Passion," 845.

97 In Ad Scap. 3.4, Tertullian names the proconsul under whom the Scillitans were persecuted. In De an. 55, he names Perpetua. Both are typically dated later than Ad mart.

98 Note that Tertullian then turns from specific persons who have suffered to various forms of suffering; e.g. 4.9: "the sword, the fire, the cross, the wild beasts, the torture" [ut gladium, ignem, crucem, bestias, tormenta]. 
the historical witnesses - wife, as an archetype of chastity and moral fortitude because she refused to marry a Roman, which leads several commentators to deduce that Tertullian salvages an indigenous account of Dido's death. ${ }^{99}$ In contrast to these two Carthaginian references, however, the Roman heroes Mucius and Regulus appear. ${ }^{100}$ Moreover, provincial examples like Heraclitus, a Sicilian, Empedocles of Greece, Cleopatra of Egypt and Leena from ancient Attica also occur. $^{101}$ One natural read is to agree with the assumption that the list signifies historical acts of bravery which carry neither negative nor positive political symbolism. ${ }^{102}$ Against such a view, however, one finds certain pointers of Tertullian in the surrounding passages of Ad martyras.

Before he lists examples of those who have undergone torture and death, Tertullian clarifies that he is encouraging women specifically. ${ }^{103}$ He introduces

99 On this translation as "hysterical," see below. For Dido, see Virgil, Aeneid 4 and Ovid, Heroides 7. cf. Tert. Ad nat. 1.18.3; 2.9.13; Apol. 50.5; De an. 33.9; De exh. chast. 13.3; De mon. 17.2. For "indigenous account," see Church, "Sex and Salvation," 97 n. 59; and Thelwall in his notes on De ex. cast. 13.3. As cited above, Spaeth, The Roman Goddess Ceres, 115, states Dido to be "the paradigm of the woman who abandons castitas."

100 Livy 2.12, presents Gaius Mucius Scaevola as both courageous and ingenious in his loyalty to Rome; Horace, Carmina 3.5, eulogized Marcus Atilius Regulus who was killed by Carthaginians, saying, "To shame ye are but adding loss; the wool with purple dyed never regains the hue it once has lost nor does true manhood, when once it has vanished, care to be restored to degenerate breasts" [flagitio additis damnumi neque amissos colores lana refert medicata fuco, nec uirtus, cum semel excidit, curat reponi deterioribus].

101 For Heraclitus, see Diogenes 9.2-4; for Empedocles, see Diogenes 8.67-75; for Cleopatra, sec Plutarch, Vitae parallelae, Ant. 54, 86; for Leena, see Pausanias 1.23; and Pliny, Naturalis historia 7.23.

102 Hoffman, The Status of Women, 169.

103 Church, "Sex and Salvation," 97, notes that half of the examples are women, only commenting that this challenges "the assumption that martyrdom may be too much to ask of women...." Schlegel, "The Ad martyras," 127 n. 2, believes the tract addressed men and women because of the use of benedicti $(1.1,1.3,1.4,3.1,3.3,5.2)$ more often than benedictae (4.3). The use of benedicti is understood here as Tertullian's gloss for the martyrs in male gender but neuter referent, a gloss he corrects in 4.3 where the martyrs' gender is explicitly addressed. If bendedictae is taken to indicate male martyrs are also addressed, then it is quite remarkable that Tertullian constructs all of the martyrs' gender as female in this section of the treatise. For feminists critiques of Tertullian, see the examples of E. Schüssler Fiorenza, "You are not to be Called Father," 311 ; Fiorenza, In Memory of Her, 55; Miles, "Patriarchy as Political Theology: The Establishment of North African Christianity," in Civil Religion and Political Theology, ed. Leroy S. Rouner, (Notre Dame, IN: University of Notre Dame Press, 1986), 172-7; and Kraemer, Her Share, 162, for Tertullian as "almost viciously misogynist." For a defense of Tertullian against these charges, see Church, "Sex and Salvation," 83-101, who concludes that women were theologically equal to men in Tertullian's wider writings; Elizabeth A. Clark, Ascetic Piety and Women's Faith: Essays on Late Ancient Christianity, (New York: Edwin Mellon Press, 1986), 23-60, who discusses both negative and positive treatment of women by early Christian writers, yet only uses negative examples from Tertullian; Heine, Women, 28, states, "Different audiences lead to different kinds of arguments" when it comes to his treatment of women; Karen Jo Torjesen, "Tertullian's 'Political Ecclesiology' and Women's Leadership," SP 21 (Louvain: Peeters, 1989): 277-282, attributes Tertullian's stance against women in 
the selection of names by stating that suffering can be found "not only in the case of men, but of women too, that you, O holy women, may be worthy of your sex. It would take me too long to enumerate one by one the men who at their own selfimpulse have put an end to themselves. As to women, there is a famous case at hand..." (nec a uiris tantum, sed etiam a feminis, ut uos quoque, benedictae, sexui uestro respondeatis. Longum est, si enumerem singulos, qui se gladio confecerint, animo suo ducti. De feminis ad manum..., 4.3-4). In light of his words, it is perplexing that Tertullian does give a list of men as well as women. More telling, the list includes five women and five men, whose deeds fall into ideologically distinct categories.

One category, that of the heroines, consists of women whose holiness (benedictae, 4.3) entails not submission but subversion. Lucretia was raped by the last prince of Rome, and her suicide brought about the end of the Roman monarchy. Dido and Hasdrubal's wife were both famous Carthaginian heroines whose acts have been discussed above. Cleopatra, Tertullian says, died "that she might not fall into the hands of her enemy" (ne in manus inimici perueniret, 4.6) - the "enemy" of course, being Octavian, soon to be "Augustus," the archetypal Roman. Leena is said to have chewed off her own tongue, denying the possibility of betraying her "confederates" (coniuratos, 4.7). All five of these heroines represent acts of solidarity against "tyranny," and all but Leena's act were in direct resistance to Rome. ${ }^{104}$

The men, on the other hand, symbolically illustrate insanity or, in Tertullian's words, "a mere vanity you find among men - in fact, a sort of mental disease" (apud homines affectatio quoque et morbus quidam animi, 5.1). In broader academic discussions, feminist scholars widely acknowledge the motif of the "hysterical" woman, wherein any woman, seen by men as acting "out of place" is

clerical roles and functions to his modeling the church after a Roman societas; Elizabeth Carnelly, "Tertullian and Feminism," Theology 92 (Ja 1989): 31-35, who argues that "misogynist"/"feminist" labels are anachronistic; and Hoffman, The Status, 148, who suggests, "...when considered within his own cultural and theological context, [Tertullian's statements] were not unusually negative, but were relatively positive." For a general introduction to feminist readings of Christian origins up to this period, see Castelli, "Heteroglossia," 73-98. It is interesting to note how the premodern editors Rhenanus, Mesnartius and Gelenius changed the title as found in the manuscripts, Ad martyras, to Ad martyres.

104 On Lucretia, see Ovid, Fasti 2.807, where Sextus Tarquinus is portrayed as saying, "Resistance is vain... I'll rob thee of honour and life" [nil agis eripiam... per crimina vitam]; also, see Ovid's retort (2.811-2), "Why victor dost thou joy? This victory will ruin thee. Alack, how dear a single night did cost thy kingdom!" [quid, uictor, gaudes? haec te uictoria perdet. heu quanto regnis nox stetit una tuis!] The incident is credited with the establishment of the Republic. Dixon, Reading Roman Women, 46, describes Lucretia as "the embodiment of the prime virtues of the Roman matron..." Additionally, Spaeth, The Roman Goddess, 115, says Lucretia was the Roman heroine antithetical to Dido because of her chastity. As for Cleopatra, the claim the she resisted Rome is somewhat dubious given her allegiance to Anthony; it is a distinction, however, that Tertullian the rhetorician did not need to acknowledge. For "tyranny," see the account of Leena by Pliny, Naturalis historia 7.23, where Leena "refused to betray tyrannicides" [non indicauit tyrannicides]. 
described as "frantic," "frenzied" and psycho-somatically unstable. ${ }^{105}$ It is, therefore, surprising to find in the infamously misogynistic writings of Tertullian an inversion of this motif; it is the men who are unstable, insane and, one could translate, "hysterical."106

Tertullian invokes politically charged language and imagery to contrast instances of impetuous suffering by men with cases of laudable martyrdom by women; he asks, "If the bit of glass is so precious, what must the true pearl be worth?" (Si tanti uitreum, quanti uerum margaritum? 4.9). By interpreting Tertullian's $A d$ martyras as politicized, his rhetoric also can be understood as gendered and feminized. Tertullian's list of martyrs is antagonistic towards Rome in that it glorifies women who have subverted Rome's oppression and who are, therefore, positive examples of martyrdom. Tertullian displays these women in contrast to the "hysterical men" who died for gloria which gives this "religious" tract a political element which is contextually charged for Carthaginian women awaiting persecution. ${ }^{107}$

Many scholars see in Tertullian's writings a sharp antagonism towards "paganism" generally and therefore towards Roman religion only implicitly. ${ }^{108}$ In Ad martyras, however, Tertullian is explicitly antagonistic towards Rome, writing from within the context of religion and religious conflict, wherein many not only resisted Romanization on a "purely" religious level - as if there were such a plane in the ancient world - but also on a socio-political level common to many Africans under Roman rule. While the Christian writer would likely denounce any religion other than Christianity as false, Tertullian specifically attacks Rome, suggesting another aspect of his own religious identity.

\subsubsection{African Christian and Roman Christian Religious Identities}

As shown in chapter one's survey of recent scholarship, scholars in the past have viewed Tertullian as a member of a schismatic body, known as Montanism, but more recently the general consensus of scholars understands Tertullian as never formally separating from the church. How then should one understand Tertullian's polemical use of "Montanistic" concepts, such as the Paraclete and

105 For the term in early Christian studies, see Lefkowitz, Heroines; and MacDonald, Early Christian Women. For a review of early Christian literature wherein "Montanist" women of Tertullian's era are hysterical, "raving," and "insane," see Trevett, "Gender, Authority and Church History: A Case Study of Montanism," Feminist Theology 17 (Ja 1998): 9-24.

106 Similarly, Bal, "Perpetual Contest," 236, finds Perpetua's father to become "hysterical" in the account of the PSPF.

107 Tertullian is fully capable of manipulating these and other examples to suit his purpose; see $D e$ an. 58, where Mucius is a positive example, and Apol. 50/Ad nat. 1.18, where some of these same women examples are used negatively.

108 e.g. Altaner, Patrology, 167, says Tertullian "attacked and ridiculed the pagan religion in general." 
new prophecies? One approach is found in D. Powell's argument that Tertullian belonged to an ecclesiola in ecclesia, which never formally removed itself from the church at large, but acted much like a "holy club" of the revivalist movements. ${ }^{109}$ Rankin, who more recently championed this understanding, examines the textual data in Tertullian's so-called "Montanist" writings and finds that Tertullian always includes the "Catholics" within his understanding of the church. ${ }^{110}$ Even more recently, William Tabbernee, a Montanism scholar, writes to confirm this understanding, stating,

This [penitential discipline] was an internal fight, within the Catholic church, not a battle between "Montanists" and "Catholics." Consequently, the term psychici which Tertullian hurls at his opponents must not be equated with "Catholics" - the members of Tertullian's house church were also "Catholics." The psychici were simply those Catholics who were not prepared to practice the rigoristic discipline of Christian living which the "spiritual persons" of Tertullian's house church (and probably also of some other house churches) practiced. ${ }^{111}$

The common factor in recent scholars' understanding that Tertullian remained in the catholic church is the evidence in his writings that he placed both his opponents, the "Psychics," and himself within any discussion of the universal body of Christians rather than labeling any one party, group or congregation as the true church. What role, then, did "Montanist" influence play in Tertullian's writings?

Nicola Denzey speaks on behalf of many church historians when she argues for the "need to reinvestigate the modern, arbitrary lines we have previously drawn between one group and another, lines that prevent us from appreciating how one early Christian group may have accommodated texts from other, earlier traditions." 112 Moreover, she aligns herself with the recent consensus that seeks to "deconstruct or refute" the arbitrary categories and labels or "academic compartmentalization" of certain "heresies." "13 One example of deconstructing scholarly tradition about "Montanism" includes the now general recognition that

109 "Tertullianists," 33-54. Robeck, Prophecy, 202; and Wright, "Tertullian," 1029, agree. cf. Tabbernee, Montanist Inscriptions, 55, who identifies Tertullian as "pro-Montanist"; and Trevett, Montanism, 69, who calls Tertullian "the Montanist Catholic." Van der Lof, "The Plebs," argues that there was not even a distinct group within the wider Christian congregation, but that Tertullian uses the term to refer to "fellow-Catholics."

110 Tertullian, 35-6.

111 "To Pardon," 385. cf. The late Christian writer of the anonymous Praedestinatorum haeresis 1.86 , "Whenever you read of Tertullian against the psychics, you should know that he is speaking against the Catholics." [Vbicumque autem legeris Tertuliani aduersum psychicos, scias eum contra catholicos agere]. On Pauline/Tertullianic use of psychici, see van der Lof, "The Plebs," 353-5; and Rankin, Tertullian, xv.

112 "What did the Montanists Read?", 447.

113 Ibid, 429. 
the title itself is anachronistic when applied to Tertullian's era. ${ }^{114}$ Long before this trend, H.J. Lawlor warned scholars that the typical approach of understanding Montanism through Tertullian is misguided, because, "Tertullian brought far more to Montanism than he found in it."115 Tertullian did refer on several occasions to "the New Prophecy" as well as its founding prophets, Montanus, Maximilla and Prisc(ill)a, and he invoked what have been labeled "Montanist teachings," such as the active working of the Paraclete and rigorist discipline. ${ }^{116}$ The following analysis of some of Tertullian's works containing these elements addresses how he used the "New Prophecy" in constructing the identies of his opponents.

The number of Tertullian's treatises considered "Montanist" by scholars varies according to the criteria used to attach such a label. ${ }^{117}$ Often, scholars use more than simply the use of "New Prophecy" or the names of Montanus, Maximilla and Prisc(ill)a, but allow any rebuttal against charges of pseudoprophetia or noua disciplina, references to the ecstatic state, use of Paracletus for the Holy Spirit, mention of spiritual gifts to be held only by "Montanists," "we" language for Montanists, "you" language for non-Montanists or any application of the title psychici to "non-Montanists." "118 The last four criteria, however, presuppose the existence of a "Montanist" group, party or a schism in North Africa. Because of the complexity involved in the scholarly reconstructions of Tertullian's "Montanism," the following discussion will focus on three of his writings almost universally considered to be influenced by the New Prophecy. In this way, the evidence drawn from the material provides examples from Tertullian's thought which unquestionably typifies his most

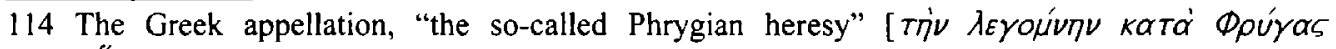
aijpeolv, Eusebius, Historia ecclesiastica 5.16.1], became the "Cataphrygian" heresy in Latin, a term more contemporary to the phenomenon. For discussion, see Alistair Stewart-Sykes, "The Original Condemnation of Asian Montanism," Journal of Ecclesiastical History 50 (Ja 1999): 1-22. Christine Trevett, "Gender," 10, claims the earliest reference to "Montanists" (Montanoi) is in Cyril of Jerusalem, Catechetical Lectures 16.8 .

115 "The Heresy," 338. Also, von Campenhausen, The Fathers, 31, "As a Montanist, Tertulian did not become other than he had always been"; Bray, "Tertullian and Western Theology," in Great Leaders of the Christian Church, ed. John D. Woodbridge, (Chicago: Moody Press, 1988), 50, "It seems probable, therefore, that Tertullian saw Montanism as a movement that advocated some of his own teachings. He was therefore inclined to rate it highly, though it is most improbable that he ever became a Montanist in the strict sense"; Tabbernee, Monstanist Inscriptions, 234, "Tertullian's views are not necessarily applicable to other Montanists"; and Dunn, Tertullian, 6, "...we do not know the extent to which he recast Montanism to suit his own inclinations..." Even Robeck, Prophecy, 124, who belived Tertullian a Montanist, discusses his use of Prise(ill)a's oracle, concluding, "It provided no new theological insight" but it "corroborated" Tertullian's opinion.

116 Tabbernee, "To Pardon," 378, surmises that Tertullian knew of the Phrygian prophetesses and prophet through literature.

117 For reviews, see Bray, Holiness, 55ff.; and more recently, Rankin, Tertullian, xiv-xvii, and 2751.

118 This list, as a standard example is taken from Barnes, Tertullian, 43-4. 
aggressive works towards "Psychics." Other so-called "Montanist" works will only be used to supplement the discussion, the aim of which is to explore how Tertullian used the "New Prophecy" to construct his own religious identity. ${ }^{119}$

Most scholars conclude that Tertullian produced the three treatises, De monogomia, De ieiunio and De pudicitia, close together, probably within a year, and they largely represent a continuation of Tertullian's arguments against his dialogical counterparts. ${ }^{120}$ In these works Tertullian writes against his religious opponents, designated as "Psychics" throughout, regarding the subjects of discipline. ${ }^{121}$ The New Prophecy, according to Tertullian, teaches strict Christian discipline, "not that Montanus and Priscilla and Maximilla preach another God, nor that they disjoin Jesus Christ (from God), nor that they overturn any particular rule of faith or hope, but that they plainly teach more frequent fasting than marrying." 22 The Paraclete for Tertullian continues to lead Christians into all truths and this appelation repeatedly appears in Tertullian's works. Tertullian can concede, however, to omit for the sake of discussion, "mention of the Paraclete, as of some authority of our own" (mentio Paracliti ut nostri alicuius auctoris, De mon. 4.1) because he believes his argument can stand on other grounds such as proofs from scripture.

Within the context of Tertullian's dispute over discipline he offers an analogy between Christ's abrogation of the teaching on marriage by Moses and the Paraclete's abrogation of the teaching on marriage by Paul: "the New Law abrogated divorce... the New Prophecy (abrogates) second marriage" (noua lex abstulit repudium... et noua prophetia secundum matrimonium, De mon. 14.5). The frequent references to the Paraclete, New Prophecy and names of particular prophets indicate that Tertullian understood what is now known as Montanism to be in opposition to some more lax forms of Christianity. Moreover, Tertullian references not only the movement in his work, but he explains something of the nature of the New Prophecy as he came to know it.

While Tertullian nowhere explains how he came to know of Montanus and other "new prophets," he does indicate what role the New Prophecy plays in his arguments. Discussing the problem of customs derived from tradition but not found in scripture, he says "we are bound to adduce so much the more worthy

119 For the accusation of heresy in opposition to new prophecy, see Eusebius, Historia ecclesiastica

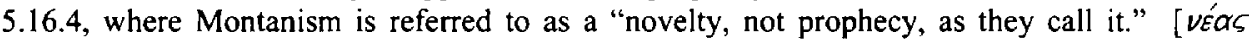

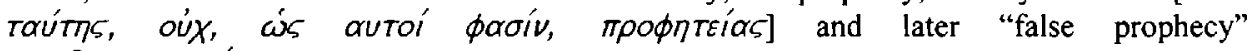

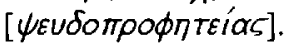

120 Most recent assumptions rely on Barnes, Tertullian, 55; Tertullian alludes to writing De mon. first: De iei. 1.4; and De pud. 1.13ff. Also, for a recent discussion of De pud. that emphasizes the context's importance for Tertullian's trinitarianism, see Andrew McGowan, "Tertullian and the 'Heretical' Origins of the 'Orthodox' Trinity," JECS 14 (4 2006): 437-457.

121 On "Psychics" [psychici], note that Tertullian, aside from two examples (Adu. Marc.4.22.5; and Adu. Prax. 1.6-7) employs the title exclusively in the three works under discussion.

122 De iei. 1.3: non quod alium deum praedicent Montanus et Priscilla et Maximilla, nec quod lesum Christum soluant, nec quod aliquam fidei aut spei regulam euertant, sed quod plane doceant saepius ieiunare quam nubere. cf. De mon. 2. 
reason... until by some signal celestial gift they be either confirmed or else corrected" (tanto magis dignam rationem adferre debemus ...donec aliquo caelesti charismate aut confirmentur aut corrigantur, De iei. 10.5). After then quoting the Apostle Paul, He declares that the Paraclete, as he concurrently speaks in the church, is "the Confirmer of all such things" (confirmatore omnium istorum, 10.6). ${ }^{123}$ Regarding certain matters of discipline, Tertullian admits that he once held a "fellowship of sentiment" (sententiae... societatem, De pud. 1.10) but later, seemingly of his own accord, came to reject his stance, which is why, "it is not lightly that the Holy Spirit has come to an agreement with us - coming to this agreement even without our asking" (non leuiter nobiscum pactus est Spiritus sanctus, etiam ultro pactus, 12.9). ${ }^{124}$ Tertullian claims the New Prophecy confirmed what he had already come to believe, and in this way it served as further proof for Tertullian and as an ally against his religious opponents. ${ }^{125}$ Tabernee affirms this understanding: "Tertullian... while never a schismatic Montanist, did find in the New Prophecy movement certain emphases consistent with the direction his own, progressively more rigorist, views on Christian praxis were heading. Tertullian's adoption of certain Montanist presuppositions enabled him both to reach those conclusions more quickly and to have at his disposal additional data to support those conclusions." 26 The understanding of the New Prophecy in Tertullian as a confirmation and an ally against his religious opponents helps to explain his sometimes ambiguous statements about the church and its members. ${ }^{127}$ How does Tertullian describe those Christians with whom he disagrees?

Beyond the application of the term psychici, Tertullian provides a few specific details about his religious opponents. According to the issue at hand in his treatise, Tertullian specifies the error of his opponents, such as the permission

123 ref. Philippians $3: 15$.

124 Dunn, Tertullian, 7, comments, "[Tertullian] did not see himself as having anything in common with Christians who did not hold to his Montanist convictions..." cf. Tertullian, Adu. Prax. 1.6, "We indeed, on our part, subsequently withdrew from the carnally-minded on our acknowledgment and maintenance of the Paraclete" [et nos quidem postea agnitio paracleti atque defensio disiunxit a psychicis]; Holmes comments that this withdrawal is from Rome, not his own Carthaginian bishop.

125 See Trevett, Montanism, 112, "If the original New Prophecy had outlawed remarriage then it came as music to Tertulian's ears and probably bolstered a distaste for remarriage which he had harboured for some time."

126 "To Pardon," 377. Most scholars agree some explanation is needed; e.g. Barnes, Tertullian, 136, who conjectures that Tertullian's wife died and his conversion to Montanism was a "psychological buttress of his belief that remarriage was wrong." Another example is Altaner, Patrology, 166, "His austere and gloomy cast of mind which abhorred neutrality and compromise led him to the Montanist sect..." For more examples of psychological explanations, see bibliography in Trevett, Montanism, 68.

127 Trevett, "Gender," 19, similarly yet conversely argues that the Catholics rejected the New Prophecy because women prophets did not fit into the "view of Christian community which would be recognizable to the Graeco-Roman world as ordered, respectable and deserving of toleration" which the Catholics were attempting to establish. 
of multiple marriages (De mon. 1.1), the sin of gluttony (De iei. 1.1-2) and the absolution of mortal sins (De pud. 1.6-8). Throughout these tracts a tenuous description of his opponents' relation to his church(es) exists.

Many passages verify the view of Rankin and others who understand Tertullian to have remained in communion with the "catholic" church. From the beginning of Tertullian's argument, he displays a distinction with his opponents and heretics: "Heretics do away with marriages; Psychics accumulate them" (Haeretici nuptias auferunt, psychici ingerunt, De mon. 1.1). ${ }^{128}$ Throughout the works, he retains the framework of one universal Church, "for our one Father, God, lives, and our mother, the Church" (uiuit enim unicus pater noster Deus et mater ecclesia, De mon. 7.9). Within his discussion, Tertullian includes his opponents, even those who remarry, stating, "We shall be with God, we shall be together, since we shall all be with the one God" (cum Deo erimus, simul erimus, dum omnes apud deum unum, De mon. 10.9). ${ }^{129}$ Expressing his horror that some absolve mortal sins,

Tertullian declares, "But it is in the church that this (edict) is read, and in the church that it is pronounced; and (the church) is a virgin!" (Sed hoc in ecclesia legitur, et in ecclesia pronuntiatur, et uirgo est, De pud. 1.8). Finally, as evidence for one of his arguments with those who are not heretics, he reminds the audience that one who has fallen into schism "attains pardon and is restored to the bosom of the Church" (ueniam consequi et in ecclesiam redigi, 19.5). While these passages indicate that Tertullian considered both psychici and those who agreed with him within one broadly inclusive church, still other statements display that Tertullian ecclesiologically distinguishes the two groups. ${ }^{130}$

In several instances often used to verify the older understanding of Tertullian as a schismatic, Tertullian refers to separate and distinct ecclesial bodies. He attacks "that bishop of Utina of yours" and the many digamists who "preside in your churches" (ille uester Vthinensis ...ex digamia praesident apud uos, De mon. 12.6-7), as well as "your presiding (elders)" (apud te praesidentibus, De iei. 17.4), in contrast to his own ecclesial community, wherein, "we excommunicate digamists" (digamos foris sistimus, De pud. 1.20). In reference to the Shepherd of Hermas, despite it having been dismissed "by every council of Churches, even of your own" (ab omni concilio ecclesiarum, etiam uestrarum, De pud. 10.12), Tertullian describes how "you depict upon your (sacramental) chalice" (in calice depingis) this very shepherd. The former statement indicates what is to Tertullian

128 On the Psychics' view of Tertullian's group, see De mon. 2.1, 15.1, De iei. 1.5, 11.2, 13.1, where some claim Tertullian's views are heretical and novel. Throughout these references the claims are treated as individual accusations, not official declarations.

129 ref. Jn. 11:21; 17; and Gal. 3:28. Also, De exh. cast. 12.6, a digamist is "among our brethren" [ex fratribus]. When writing against "heretics" (e.g. Marcion, Hermogenes, etc.), however, Tertullian makes no such stipulations.

130 Tertullian is capable, even in his so-called "Montanist" writings, of locating Christians from various regions in "one church" [una ecclesia, De uirg. uel. 2.3.] Evans, One and Holy, 27, believes Tertullian's statement is inclusive of "psychics" and "Montanists." 
a distinct conciliar body from councils with which he identifies, and the latter a different sacramental setting. These passages suggest more than an ecclesiola in ecclesia; Tertullian distances his community from the sacramental and episcopal community of the psychici. How then can one understand the previous passages which indicated the two groups to exist within the same communion? Further passages found in Tertullian's work allow for a distinction based on geography.

The data gleaned from the many passages which describe Tertullian's religious opponents include references specifying those opponents as Roman. ${ }^{131}$ Seemingly out of place in an internal ecclesiological dispute, Tertullian remarks how divorce was not recognized "among the Romans,... not till after the six hundredth year from the building of the city" (apud Romanos post annum sexcentesimum Vrbis conditae, De mon. 9.11). He then returns to such language about the legality of marriage, and states, "The case is different if men believe that, at the bar of Christ as well (as of Rome), action is taken on the principle of the Julian laws" (Aliud est si et apud Christum legibus Iuliis agi credunt, De mon. 16.6). Moreover, in the final days, "there will arise a queen of Carthage" (exsurget regina Carthaginis, De mon. 17.2) - Dido - and "her assessor will be the Roman matron" (Assidebit et illi matrona Romana, De mon. 17.3) - Lucretia - to judge the psychics. ${ }^{132}$

Concerning the relationship between the local and the universal church, Tertullian explains,

Besides, throughout the provinces of Greece there are held in definite localities those councils gathered out of the universal Churches, by whose means not only all the deeper questions are handled for the common benefit, but the actual representation of the whole Christian name is celebrated with great veneration. (And how worthy a thing is this, that, under the auspices of faith, men should congregate from all quarters to Christ! "See, how good and how enjoyable for brethren to dwell in unity!" This psalm you know not easily how to sing, except when you are supping with a goodly company!) But those conclaves first, by the operations of Stations and fastings, know what it is "to grieve with the grieving," and thus at last "to rejoice in company with the rejoicing." If we also, in our diverse provinces, (but) present mutually in spirit, observe those very solemnities, whose then celebration our present discourse has been defending, that is the sacramental law. ${ }^{133}$

131 However, see Fredouille, Tertullien, 290; and Tabbernee, Montanist Inscriptions, 59, who assumes pyschici refer to Carthaginian Christians who were not "pro-Montanist"; also, Trevett, Montanism, 73-6.

132 Tertullian's "queen of Carthage" blurs Dido and the ref. in Matt. 12:42. For Lucretia, see Mattei, Le marriage unique, 394.

133 De iei. 13.6-8: Aguntur praeterea per Graecias illa certis in locis concilia ex uniuersis ecclesiis, per quae et altiora quaeque in commune tractantur, et ipsa repraesentatio totius nominis Christiani magna ueneratione celebratur. Et hoc quam dignum fide auspicante congregari undique ad Christum! Vide, quam bonum et quam iucundum habitare fratres in unum! Hoc tu psallere non facile nosti, nisi quo tempore cum compluribus cenas. Conuentus autem illi stationibus prius et ieiunationibus operati dolere cum dolentibus et ita demum 
Tertullian derides Romans who reject the New Prophecy and who can only rejoice in "goodly company," (compluribus) in other words, not with those from "diverse provinces" such as Greece or Africa Proconsularis. ${ }^{134}$

Much scholarly debate centres around the pontifex maximus, also entitled, episcopus episcoporum (De pud. 1.6) attacked by Tertullian. ${ }^{135}$ Barnes has argued that Tertullian's reference is to the bishop of Carthage, rather than Rome. ${ }^{136}$ Many, however, disagree on the grounds that Tertullian's use of irony points to the region of the "Pontifex Maximus" of the non-Christian world. ${ }^{137}$ One of the most compelling reasons for understanding Tertullian to be arguing against Rome is found in another of his works, Aduersus Praxean, written

congaudere gaudentibus norunt. Si et ista sollemnia, quibus tunc praesens patrocinatus est sermo, nos quoque ini diuersis prouinciis fungimur in spiritu inuicem repraesentati, lex est sacramenti; ref. Ps. 133:1; and Rom. 12:15.

134 Another passage that could be read from a postcolonial understanding is Tertullian's remarks in De pud. 8.1 about sewing together two clothes of "purple" that do not match; i.e. imperial and Tyrean.

$135 \mathrm{cf}$. De pud. 21 for an assortment of Petrine references that could refer to the authority of Peter claimed at Rome or that authority inherent in every bishop succeeding from Peter. For the accusation that Tertullian attacked Soter [as bishop $c$. 167-174], see Praedestinatorum haeresis 1.26, "While Tertullian wrote all things well, first-rate, and incomparably, he made himself reprehensible only in this, that he defended Montanus, acting contrary to Soter, pope of Rome" [Qui cum omnia bene et primae et incomparabiliter scripserit, in hoc solum se reprehensibilem fecit, quod Montanum defendit, agens contra Soterum supra dictum urbis papam]; and Praedestinatorum haeresis 1.86, "We read that the Tertullianists were once condemned by the Roman pope Soter." [Tertullianistas olim a Sotere papa Romano damnatos legimus]. G. Salmon, "Montanism," in A Dictionary of Christian Biography, Literature, Sects and Doctrines: During the First Eight Centuries vol 3, eds. William Smith and Henry Wace, (London: John Murray, 1882), 938, says Eleutherius [as bishop c. 174-189] was the first bishop of Rome to make any decision in regards to Montanism, and that the author cited here "is not a blunderer but a willful liar; ... In a later section, Predestinatus outrages all chronology by making Soter condemn Tertullian." However, because of most chronologies of Tertullian's works, Callistus of Rome is often identified as the referent; e.g. J.E. Merdiger, Rome and the African Church in the Time of Augustine, (YUP, 1997), 32. cf. Tert., De praes. 30.1, "blessed Eleutherus" [Eleutherii benedicti].

136 Barnes, Tertullian, 141; for an earlier example, von Campenhausen, The Fathers, 34; more recently, Rankin, Tertullian, 62; Tabernee, "To Pardon or not to Pardon?", 376, citing Bames; and, Wright, "Tertullian," 1042.

137 Some recent examples include, A. Brent, Hippolytus and the Roman Church in the Third Century, (New York: Brill, 1995), 503-35; Evans, One and Holy, 32, who claims it is overwhelmingly probable"; Merdinger, Rome, 32-3; Osborn, Tertullian, 175, note 31. The title pontifex maximus in Tertullian's day referred to the high priest of all municipal Roman religions, and was not claimed by the bishop of Rome until later. If Tertullian is criticizing the bishop of Rome, he would likely be following the example set by Irenaeus in the Paschal controversy; see Eusebius, Historia ecclesiastica 5.24.2; and discussion in Elliot-Binns, The Beginnings, 106-7. 
possibly within "a few weeks" of the three treatises under discussion. ${ }^{138}$ While the document has been left aside up to the present because its primary subject is the patripassian controversy of a certain Praxeas, Tertullian does reference the opposition with the Psychics at play in De monogomia, De ieiunio and De pudicitia:

For after the Bishop of Rome had acknowledged the prophetic gifts of Montanus, Prisc[ill]a and Maximilla, and, in consequence of the acknowledgment, had bestowed his peace on the churches of Asia and Phrygia, [Praxeas], by importunately urging false accusations against the prophets themselves and their churches, and insisting on the authority of the bishop's predecessors in the see, compelled him to recall the pacific letter which he had issued, as well as to desist from his purpose of acknowledging the said gifts. ${ }^{139}$

Tertullian knows of the bishop of Rome's actions in detail and writes in opposition to the stance of the Roman church. ${ }^{140}$

While Tertullian focuses on other matters in Aduersus Praxean, he addresses the issue mentioned in the three works on Christian discipline. ${ }^{141}$ Throughout those works, the many Romanisms, such as Julian law and the pontif and flamen (De mon. 17.4), illustrate the religious conflict between two groups in Tertullian's thought: North African Christians and the Roman church. This understanding

138 Barnes, Tertullian, 47; however, Fredouille, Tertullien, 488, spreads them over approximately four years.

139 Adu. Prax. 1.5: Nam idem tunc episcopum Romanum, agnoscentem iam prophetias Montani, Priscae, Maximillae, et ex ea agnitione pacem ecclesiis Asiae et Phrygiae inferentem, falsa de ipsis prophetis et ecclesiis eorum adseuerando et praecessorum eius auctoritates defendendo coegit et litteras pacis reuocare iam emissas et a proposito recipiendorum charismatum concessare.

140 It is interesting to note that the bishop was likely Victor, the first African bishop of Rome: (Ps.)Tertullian, Aduersus omnes haereses. 7, names him to be "Victorinus," identified as Victor by Thelwall; and P. Holmes, $A N F$ (1885), note 8, comments that the bishop was "Probably Victor." Likewise, Evans, Tertullian Treatise Against Praxeas, 76, believes this passage refers not to Eleutherus, but Victor who "was inclined to approve of the prophets" until Praxeas persuaded otherwise. Also, Hoffman, The Status of Women, 172-4, apparently on the basis of Tertullian's statement ( $A d u$. Prax. 1.5, see above), believes Tertullian refers to Victor as the "devil." On the other hand, Trevett, Montanism, 58, believes the refence is to Eleutherus. Moreover, it should be acknowledged that the bishop referenced in De pud. need not be the same as Adu. Prax.; Robeck, Prophecy in Carthage, 124, believes the grantor of peace was "most likely Eleuterus," but it was Victor whom Praxeas persuaded. If the reference(s) were taken to indicate Victor, however, it would reinforce the view that Tertullian was antagonistic towards African new elites who were closely aligned with Rome; see Elliot-Binns, The Beginnings, 105, who conjectures that many African Christians resided in Rome at this time.

141 McGowan, "Tertullian," 451, also links the audience of these treatises - albeit for different reasons. 
provides an explanation for how Tertullian can speak of one universal church, in which belong both his group and the Psychics, and still delineate two ecclesial communities with distinguishable councils, bishops and even chalices, each representing different religious identities. 